Research article

\title{
Background concentrations and quality reference values for some potentially toxic elements in soils of São Paulo State, Brazil
}

\author{
Thiago Assis Rodrigues Nogueira, ${ }^{\mathrm{a}, *}$, Cassio Hamilton Abreu-Junior ${ }^{\mathrm{a}, \mathrm{b}}$, \\ Luís Reynaldo Ferracciú Alleoni ${ }^{\mathrm{c}}$, Zhenli $\mathrm{He}^{\mathrm{d}}$, Marcio Roberto Soares ${ }^{\mathrm{e}}$, Camila dos Santos Vieira ${ }^{\mathrm{b}}$, \\ Luís Gustavo Frediani Lessa ${ }^{\mathrm{f}}$, Gian Franco Capra ${ }^{\mathrm{g}, \mathrm{h}, * *}$
}

a Department of Plant Protection, Rural Engineering and Soils, School of Engineering, São Paulo State University, Ilha Solteira, SP, 15.385-000, Brazil

${ }^{\mathrm{b}}$ Department of Plant Nutrition, Center for Nuclear Energy in Agriculture, University of São Paulo, Piracicaba, SP, 13400-970, Brazil

${ }^{\mathrm{c}}$ Department of Soil Science, Luiz de Queiroz College of Agriculture, University of São Paulo, Piracicaba, SP, 13418-900, Brazil

${ }^{\mathrm{d}}$ Institute of Food and Agricultural Sciences, Indian River Research and Education Center, University of Florida, Fort Pierce, FL, 34945-3138, USA

e Department of Natural Resources and Environmental Protection, Agricultural Sciences Centre, Federal University of São Carlos, Araras, SP, 13600-970, Brazil

${ }_{\mathrm{f}}^{\mathrm{f}}$ Department of Soils and Environmental Resources, College of Agricultural Sciences, São Paulo State University (UNESP), 18.610-307, Botucatu, SP, Brazil

${ }^{g}$ Dipartimento di Architettura, Design e Urbanistica, Università degli Studi di Sassari, Via Colombo n॰; 1,08100 , Nuoro, Italy

h Desertification Research Centre, Università degli Studi di Sassari, Viale Italia n; 39, 07100, Sassari, Italy

\section{A R T I C L E I N F O}

\section{Keywords:}

Guideline values

Environmental monitoring

Soil quality

Soil contamination

Multivariate statistic

\begin{abstract}
A B S T R A C T
Quality reference values (QRV) for potentially toxic elements (PTE) in soils are established as a tool for prevention and monitoring of soil pollution. These values should be periodically revised in order to ensure soil safety for agricultural purposes. Brazil is market leader for several commodities; therefore, the safety of Brazilian soils is of worldwide strategic importance. The objective of this study was to determine the natural background concentrations and the QRV for $\mathrm{As}, \mathrm{Ba}, \mathrm{Cd}, \mathrm{Cr}, \mathrm{Ni}, \mathrm{Pb}$, Se, and $\mathrm{Zn}$ by investigating 30 representative pedotypes in the São Paulo State, one of the most important agro-industry economy at worldwide level. Multivariate statistical analysis was applied to determine the sources of PTE and their variability. The mean natural background concentrations of PTE in the soils were generally lower to those reported in literature. QRV, calculated for each element as the 75th and 90th percentiles, were lower (75th for As, $\mathrm{Cd}, \mathrm{Pb}$, and $\mathrm{Zn}$ ), similar (75th for Ba, $\mathrm{Cr}$, and $\mathrm{Se}$ ) or above (90th for Ba, Cr, and Se and 75-90th for Ni) those previously proposed by the Brazilian environmental protection agencies. The results indicate that 75th percentile may be too restrictive. The PTE in the investigated soils appear to have comes mainly from two primary natural sources: a prevalent one of geogenic and a secondary of pedogenic origin. These results confirm the predominant natural source of selected PTE in the investigated soils, thus sustaining the possibility of using the data set to develop QRV for the State of São Paulo.
\end{abstract}

\section{Introduction}

The term potentially toxic elements (PTE, Alloway, 1995) is referred to a group of elements, such as $\mathrm{As}, \mathrm{Ba}, \mathrm{Cd}, \mathrm{Cr}, \mathrm{Ni}, \mathrm{Pb}, \mathrm{Se}$, and $\mathrm{Zn}$. This term is more inclusive and appropriate than toxic or heavy metals as it embraces metals, metalloids, nonmetals and other elements in soilplant-animal systems (Coppola et al., 2010). PTE occurs naturally in soils and are influenced by both natural factors (parent materials and pedogenesis) and anthropogenic activities (Zhao et al., 2007).

Environmental monitoring of PTE is important for controlling their concentrations in the environment, particularly in agricultural soils (Chrzan, 2016). The natural background concentrations of PTE in soils with no or minimal human influences, represent an important level used for establishing threshold values in order to differentiate contaminated from "clean" soils (Coppola et al., 2010). These values can serve as legislative tools for developing guideline values for soil pollution prevention, control and, remediation activities if necessary.

The Brazilian legislation has been characterized by a very innovative regulatory approach in the last decade and establishes the following three guiding values: 1 ) quality reference (QRV) representing the natural concentrations of chemical elements in soils without anthropic influence, i.e., soil background concentration; 2) a prevention value (PV) representing a sort of alert; and 3) an intervention value (IV) for agricultural, residential, and industrial areas (threshold value).

\footnotetext{
* Corresponding author.

** Corresponding author. Dipartimento di Architettura, Design e Urbanistica, Università degli Studi di Sassari, Via Colombo no; 1, 08100 Nuoro, Italy.

E-mail addresses: tarnogueira@agr.feis.unesp.br (T.A.R. Nogueira), pedolnu@uniss.it (G.F. Capra).
} 


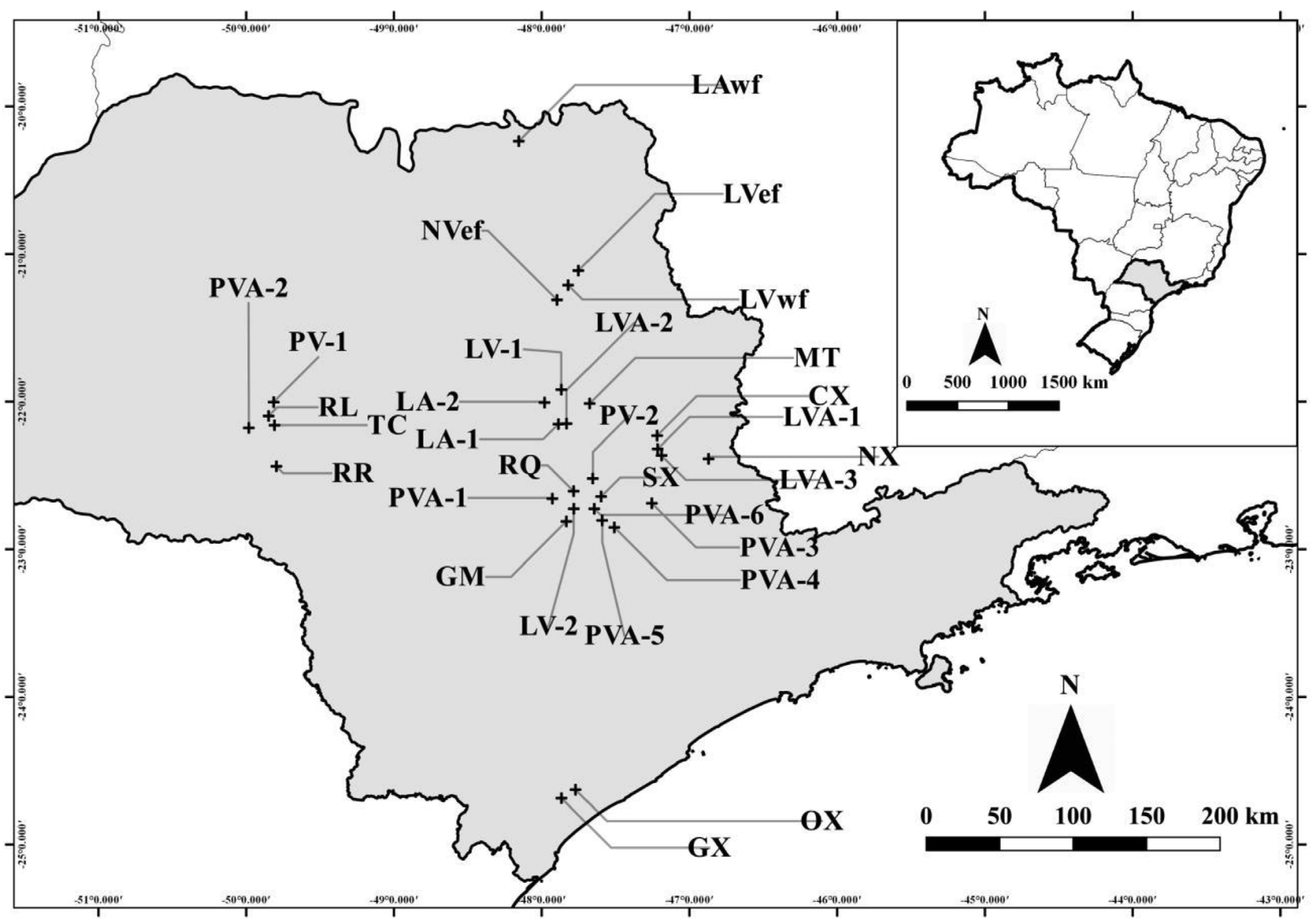

Fig. 1. Study area and sampling locations in São Paulo State, Brazil.

While the PV and IV are established by the CONAMA Resolution (human health-based risk), and valid for the whole country, whereas QRV must be determined by each state (CONAMA, 2009). Consequently, studies have been carried out to establish QRV for some Brazilian regions (Paye et al., 2010; Biondi et al., 2011; Santos and Alleoni, 2012; Gabos et al., 2014; Oliveira et al., 2014; Preston et al., 2014; Almeida Júnior et al., 2016; Silva et al., 2017). However, a lot of areas have been partially or totally neglected. This cannot be considered as a Brazilian concern only; Brazil is market leader for several commodities such as corn (Zea mays L.), sugarcane (Saccharum officinarum L.) for sugar and ethanol production, meat, coffee (Coffea sp.), soybean (Glycine sp.) and ethanol, which have been exported to worldwide (USDA, 2017), making Brazil the "breadbasket of the world" (Seibel, 2007). Therefore, the safety of Brazilian soils for agricultural production is of worldwide strategic importance for food safety.

QRV are established through statistical interpretation of natural concentrations in soil samples from a specific region, taking into account soil types and physical-chemical properties (Malkoc and Yazici, 2017). Since the Brazilian territory is extremely wide, being the 5th largest country in the world, with a consequent huge pedovariability, it is essential to assess the PTE natural background concentrations at a regional scale. This is crucial in order to establish reliable limits between natural and anthropogenic concentrations. In the absence of PTE background values, Brazilian environmental protection agencies still use international generic values (CETESB, 2014, 2016). This is a rather paradoxical situation since such values were often established for totally different conditions, in terms of both geological and pedological processes. Consequently, the use of these values may lead to incorrect risk estimation and subsequent socio-economic consequences.
Few studies have been carried out to validate the existing guiding values (CETESB, 2014, 2016). The aim of the present study was to determine the natural background concentrations and the QRV for As, $\mathrm{Ba}, \mathrm{Cd}, \mathrm{Cr}, \mathrm{Ni}, \mathrm{Pb}, \mathrm{Se}$, and $\mathrm{Zn}$ in representative pedotypes of São Paulo State, representing the most important area of Brazil in terms of economy and agricultural activities and one of the most important agroindustry economy at worldwide level (IBGE, 2014). Additionally, multivariate statistical analysis was applied to determine the origin of the observed variability and to distinguish the main sources of the investigated PTE.

\section{Materials and methods}

\subsection{Study area}

The study area is located in the São Paulo State, Brazil (Fig. 1). It is characterized by 44 million inhabitants living in an area of around $250,000 \mathrm{~km}^{2}$ (Gabos et al., 2014), representing the Brazil's biggest consumer market and agro-industry economy, contributing 33\% of the Brazilian Gross National Product (IBGE, 2014).

According to Köppen the climate is strongly influenced by relief variation: tropical wet and dry (Aw) in the shore coastline (mean T $20^{\circ}$ $22^{\circ} \mathrm{C}$; mean P $4154 \mathrm{~mm}$ ); humid subtropical (Cwa) in the plateau $\left(20^{\circ} \mathrm{C} ; 1300 \mathrm{~mm}\right)$; tropical wet and dry (As) in the northwest region $\left(24^{\circ} \mathrm{C} ; 1000-1250 \mathrm{~mm}\right)$; humid subtropical (Cfa) in the south region $\left(18^{\circ}-20^{\circ} \mathrm{C} ; 1500 \mathrm{~mm}\right)$. The natural vegetation is dominated by Atlantic forest along the shores and around the plateau. The remaining areas had fragments of semideciduous forest and a vegetation including formations of the Cerrado biome, such as clean grass fields, grassland with 
Table 1

Physical and chemical attributes of soil samples from São Paulo State, Brazil $(n=30)$.

\begin{tabular}{|c|c|c|c|c|c|}
\hline & Min & Max & Mean & Median & SE \\
\hline $\mathrm{pH}_{(\mathrm{H} 2 \mathrm{O})}$ & 4.0 & 7.3 & 5.2 & 5.3 & 0.1 \\
\hline $\mathrm{pH}_{(\mathrm{KCl})}$ & 3.2 & 6.7 & 4.2 & 4.0 & 0.1 \\
\hline Clay $\left(\mathrm{g} \mathrm{kg}^{-1}\right)$ & 40 & 716 & 305 & 245 & 35 \\
\hline Silt $\left(\mathrm{g} \mathrm{kg}^{-1}\right)$ & 20 & 448 & 212 & 207 & 25 \\
\hline Sand $\left(\mathrm{g} \mathrm{kg}^{-1}\right)$ & 75 & 880 & 482 & 530 & 45 \\
\hline $\mathrm{OC}\left(\mathrm{g} \mathrm{kg}^{-1}\right)$ & 6.7 & 213.4 & 45.3 & 33.3 & 9.0 \\
\hline $\mathrm{P}\left(\mathrm{mg} \mathrm{kg}^{-1}\right)$ & 1.1 & 76.3 & 11.6 & 5.2 & 3.0 \\
\hline CECt $\left(\mathrm{mmol}_{\mathrm{c}} \mathrm{kg}^{-1}\right)$ & 7.0 & 137.8 & 51.8 & 43.4 & 6.6 \\
\hline CECe $\left(\mathrm{mmol}_{\mathrm{c}} \mathrm{kg}^{-1}\right)$ & 4.9 & 105.5 & 33.2 & 23.8 & 4.4 \\
\hline $\mathrm{K}\left(\mathrm{mmol}_{\mathrm{c}} \mathrm{kg}^{-1}\right)$ & 0.3 & 5.2 & 1.7 & 1.2 & 0.2 \\
\hline $\mathrm{Ca}\left(\mathrm{mmol}_{\mathrm{c}} \mathrm{kg}^{-1}\right)$ & 1.3 & 82.1 & 17.8 & 12.2 & 3.5 \\
\hline $\mathrm{Mg}\left(\mathrm{mmol}_{\mathrm{c}} \mathrm{kg}^{-1}\right)$ & 0.6 & 25.2 & 7.1 & 5.1 & 1.2 \\
\hline $\mathrm{Al}\left(\mathrm{mmol}_{\mathrm{c}} \mathrm{kg}^{-1}\right)$ & 0.7 & 41.0 & 6.6 & 1.4 & 1.9 \\
\hline $\mathrm{H}+\mathrm{Al}\left(\mathrm{mmol}_{\mathrm{c}} \mathrm{kg}^{-1}\right)$ & 3.0 & 124.2 & 25.1 & 16.7 & 4.9 \\
\hline $\mathrm{SB}\left(\mathrm{mmol}_{\mathrm{c}} \mathrm{kg}^{-1}\right)$ & 2.5 & 104.5 & 26.6 & 18.2 & 4.7 \\
\hline BS (\%) & 7 & 95 & 49 & 53 & 5 \\
\hline$m(\%)$ & 1 & 81 & 28 & 16 & 5.4 \\
\hline $\mathrm{SiO}_{2-\mathrm{AE}}\left(\mathrm{g} \mathrm{kg}^{-1}\right)$ & 13.5 & 236.8 & 99.9 & 93.5 & 12.0 \\
\hline $\mathrm{Al}_{2} \mathrm{O}_{3-\mathrm{SA}}\left(\mathrm{g} \mathrm{kg}^{-1}\right)$ & 9.8 & 247.9 & 96.0 & 69.0 & 13.6 \\
\hline $\mathrm{Fe}_{2} \mathrm{O}_{3-\mathrm{SA}}\left(\mathrm{g} \mathrm{kg}^{-1}\right)$ & 6.8 & 331.8 & 76.1 & 29.6 & 17.8 \\
\hline $\mathrm{Mn}_{2} \mathrm{O}_{3-\mathrm{SA}}\left(\mathrm{g} \mathrm{kg}^{-1}\right)$ & 0.10 & 3.80 & 0.82 & 0.40 & 0.18 \\
\hline $\mathrm{TiO}_{2-\mathrm{SA}}\left(\mathrm{g} \mathrm{kg}^{-1}\right)$ & 1.5 & 45.1 & 12.7 & 6.6 & 2.6 \\
\hline $\mathrm{Fe}_{2} \mathrm{O}_{3-\mathrm{OXA}}\left(\mathrm{g} \mathrm{kg}^{-1}\right)$ & 0.2 & 19.3 & 3.9 & 1.7 & 0.9 \\
\hline $\mathrm{Al}_{2} \mathrm{O}_{3-\mathrm{OXA}}\left(\mathrm{g} \mathrm{kg}^{-1}\right)$ & 0.2 & 9.9 & 2.4 & 1.1 & 0.5 \\
\hline $\mathrm{Mn}_{2} \mathrm{O}_{3-\mathrm{OXA}}\left(\mathrm{g} \mathrm{kg}^{-1}\right)$ & 0.00 & 3.25 & 0.41 & 0.09 & 0.14 \\
\hline $\mathrm{Fe}_{2} \mathrm{O}_{3-\mathrm{CBD}}\left(\mathrm{g} \mathrm{kg}^{-1}\right)$ & 3.0 & 208.2 & 48.3 & 20.5 & 10.7 \\
\hline $\mathrm{Ki}$ & 0.8 & 4.5 & 2.2 & 2.2 & 0.2 \\
\hline $\mathrm{Kr}$ & 1.4 & 4.6 & 2.7 & 2.5 & 0.1 \\
\hline
\end{tabular}

$\mathrm{SA}=$ sulfuric acid digestion; $\mathrm{AE}=$ alkaline extraction; $\mathrm{OXA}=$ ammonium oxalate; $\mathrm{CDB}=$ sodium dithionite-citrate-bicarbonate; $\mathrm{SE}=$ standard error.

shrubs, and the Cerrado strictu senso (short savannah, mainly arbustive and herbaceous), and the forest formation of "cerradão" (closed savanna approaching a forest). The dominating soil types are Oxisols, Ultisols, Alfisols, Entisols, Inceptisols, Histosols, and Mollisols (Supplementary file 1).

\subsection{Soil sampling and analysis}

Surface soil samples (A horizon, $0-20 \mathrm{~cm}$ ) from 30 representative soil profiles were collected in the areas of native vegetation and/or ancient reforestation (Fig. 1). These profiles were selected according to a preliminary GIS (by consulting and assessing soil, geological, and geomorphological maps) and field campaign (aiming to identify the more representative pedotypes). At the end, 30 locations were selected for soil profile sampling in order to ensure that the main geological, geomorphological and pedological conditions were represented (Supplementary file 1). This phase was crucial for investigating natural soils that are representative of the lithology, topography, and climate of the investigated state. Although the conditions of environments totally free from anthropic influence are rarely found, this is the first step to identify natural conditions.

The selected Pedons were described using standard soil survey methodology (Schoeneberger et al., 2012) and classified according to Soil Survey Staff (2014).

Soil physical-chemical analyses were performed on air-dried $<2$ $\mathrm{mm}$ soil according to the official Brazilian procedures (Raij et al., 2001) in compliance with international standards. The densimeter method was used for particle-size analysis. Soil $\mathrm{pH}$ was measured potentiometrically in a soil/solution mixture of 1:2.5 $\mathrm{H}_{2} \mathrm{O}, 1: 2.51 \mathrm{M} \mathrm{KCl}$. Organic carbon (OC) content in soil was estimated by the Walkley-Black method. Available amounts of $\mathrm{P}, \mathrm{Ca}^{2+}, \mathrm{K}^{+}$and $\mathrm{Mg}^{2+}$ in soils were estimated by an ion-exchange resin procedure. Phosphorous concentration in soil extracts was quantified by colorimetric method; Ca and $\mathrm{Mg}$ were determined by atomic absorption spectrophotometer
(AAS) (VARIAN SpectrAA 220FS), while $\mathrm{K}$ in a flame-photometer (METEOR NAK-II). Exchangeable $\mathrm{Al}$ was extracted and determined with $1 \mathrm{M} \mathrm{KCl}$ and $0.025 \mathrm{M} \mathrm{NaOH}$ solutions, respectively. Total acidity $(\mathrm{H}$ $+\mathrm{Al}$ ) was extracted with buffer solution of calcium acetate $\mathrm{pH} 7.0$ and determined by titration with ammonium hydroxide $(0.025 \mathrm{M})$. From these values, the sum of exchangeable cations (SB = $\mathrm{Ca}^{2+}+\mathrm{Mg}^{2+}+\mathrm{K}^{+}$), the total cation exchange capacity (CEC) at $\mathrm{pH}$ 7.0 $\left[\mathrm{CEC}_{\mathrm{T}}=\mathrm{SB}+(\mathrm{H}+\mathrm{Al})\right]$, saturation of exchangeable cations $[\mathrm{BS} \%$ $\left.=(\mathrm{SB} \times 100) / \mathrm{CEC}_{\mathrm{t}}\right]$ and aluminum saturation $\left[m \%=\left(\mathrm{Al}^{3+} \times 100\right) /\right.$ $\left.\left(\mathrm{SB}+\mathrm{Al}^{3+}\right)\right]$ were obtained.

Iron, $\mathrm{Al}, \mathrm{Mn}$, and $\mathrm{Ti}$ contents in soil, expressed as oxides $\left(\mathrm{Al}_{2} \mathrm{O}_{3}\right.$, $\mathrm{Fe}_{2} \mathrm{O}_{3}, \mathrm{TiO}_{2}$, and $\mathrm{MnO}$ ), were extracted using $9 \mathrm{M} \mathrm{H}_{2} \mathrm{SO}_{4}$. Silicon was determined with $1 \mathrm{M} \mathrm{NaOH}$ and expressed as $\mathrm{SiO}_{2}$. Fe, Mn, and $\mathrm{Al}$ concentration in the extracts were determined using AAS, Ti by colorimetry and $\mathrm{Si}$ by gravimetry. $\mathrm{Ki}\left(\mathrm{SiO}_{2} \% \mathrm{x} 1.7 / \mathrm{Al}_{2} \mathrm{O}_{3} \%\right)$ and $\mathrm{Kr}\left(\mathrm{SiO}_{2} \% \mathrm{x}\right.$ $\left.1.7 /\left[\mathrm{Al}_{2} \mathrm{O}_{3} \%+\left(\mathrm{Fe}_{2} \mathrm{O}_{3} \% \mathrm{x} 0.64\right)\right]\right)$ indexes were used to indicate the degree of weathering of the soils and the degree of alteration of minerals in soils, respectively.

Sodium dithionite-citrate-bicarbonate solution was used to extract the well crystalline contents of iron from iron oxides; the concentration of poorly crystalline oxides of $\mathrm{Fe}, \mathrm{Al}$, and $\mathrm{Mn}$ was extracted by oxalate extraction at $\mathrm{pH} 3$.

\subsection{PTE extraction method and quality control}

All investigated PTE (As, $\mathrm{Ba}, \mathrm{Cd}, \mathrm{Cr}, \mathrm{Ni}, \mathrm{Pb}, \mathrm{Se}$, and $\mathrm{Zn}$ ) were extracted according to USEPA-3051A (USEPA, 2007), which is the official method for determining QRVs for Brazilian soils. In brief, $0.5 \mathrm{~g}$ of sieved samples $(\varnothing<0.2 \mathrm{~mm})$ was transferred into Teflon digestion vessels, and $10 \mathrm{~mL}$ of concentrated $\mathrm{HNO}_{3}$ (ICP-MS grade) was added and left to react for $15 \mathrm{~min}$. Next, the tubes were sealed and placed in a microwave oven (TC plus labstation, Milestone, Sorisole, Italy) set at $260 \mathrm{~W}$ and $415 \mathrm{kPa}$ for $10 \mathrm{~min}$ at $175^{\circ} \mathrm{C}$. The extracts were cooled to room temperature and then filtered and diluted with type 1 water (resistivity at $25^{\circ} \mathrm{C} \geq 18.2 \mathrm{M} \Omega \mathrm{cm}$, TOC $\leq 5 \mu \mathrm{g} \mathrm{L}{ }^{-1}$, prepared using a Milli-Q purification system - Millipore, Bedford, MA, USA) in $50 \mathrm{~mL}$ round-bottomed flasks. PTE in the digests were determined by inductively coupled plasma mass spectrometry (ICP-MS) (Model Agilent 7500ce).

All analyses were carried out in triplicates and blank samples were analyzed simultaneously. In order to ensure very low limits of detection all acids, reagents and water were ICP-MS compatible grade. The detection limit (DL) was calculated according to INMETRO (2003). Standard reference materials (SRM 2709a - San Joaquim and SRM 2710 - Montana Soil) were used to assure the accuracy and precision of the analytical methods. The recovery of metals in SRM was within $89-124 \%$, representing the recommended range for the investigated elements (USEPA, 1996).

\subsection{Statistical analysis}

Univariate and multivariate statistical analysis were performed using the version 9.2. of SAS (SAS Institute, 2010) and 4.0 of CANOCO software programs (Ter Braak and Smilauer, 1998).

As recommended by CONAMA (2009), the following procedure was adopted to establish QRV: $i$ ) anomalous values (outliers) were removed, before any further elaboration, by identifying them through a boxplot analysis; ii) QRV were established based on 75th and 90th percentile (sample universe).

Correlation matrix (CM) was elaborated to understand the PTE-soil properties relationships. Pearson's product moment correlation coefficient was used for Box-Cox transformed data with statistical significance determined with the Student's $t$-test (Capra et al., 2014).

A principal component analysis (PCA) was performed to select the (group of) soil attributes that affect PTE natural concentrations in the soil in terms of both variability and main sources. PCA is a technique that indicates associations between variables by reducing the size of the 

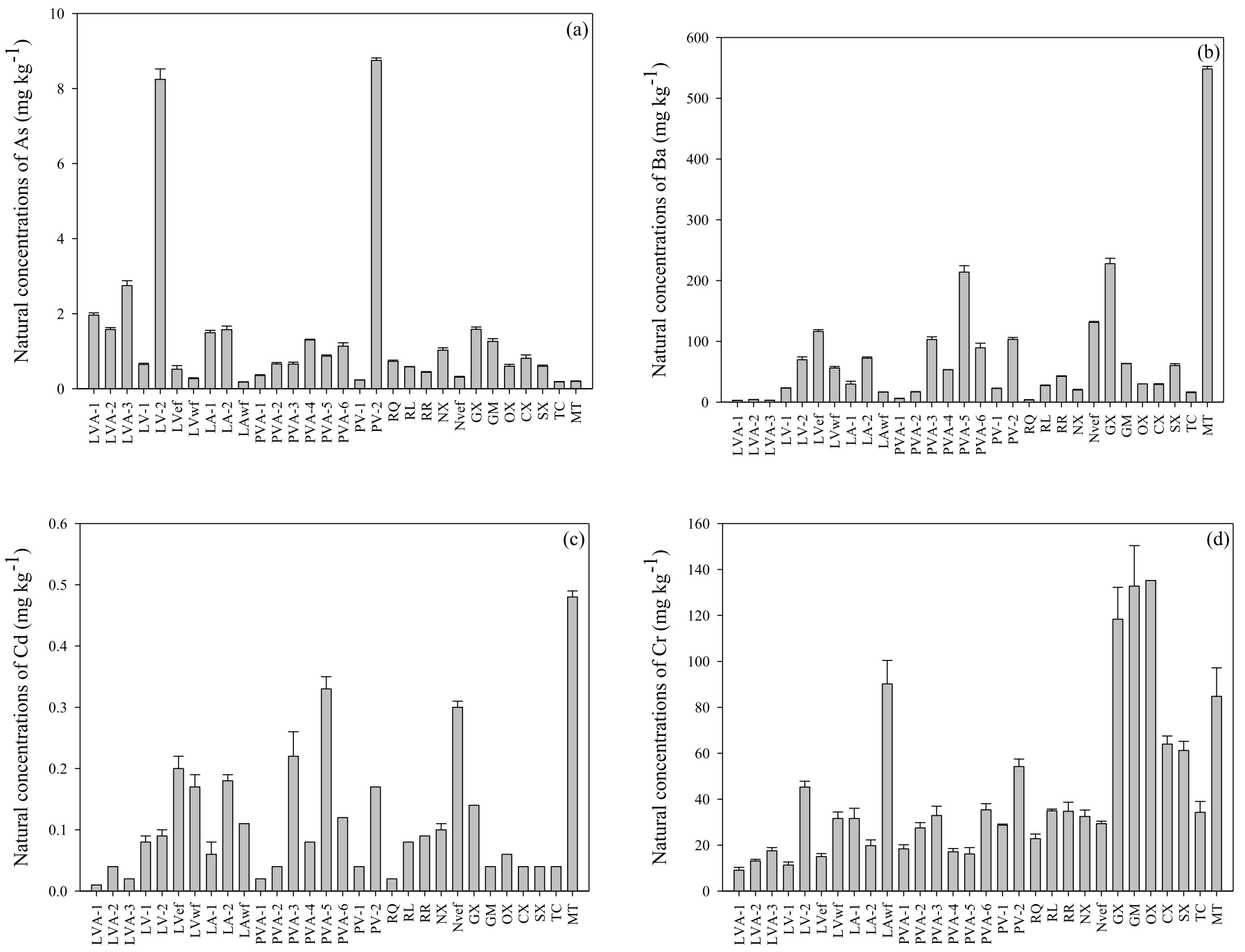

Fig. 2. Concentrations of As (a), Ba (b), Cd (c) and Cr (d) in natural soils from São Paulo State, Brazil.

number of data, conserving most of the useful statistical information present in the original data, and grouping them with greater similarity (Capra et al., 2014). Biplots were applied to establish crucial variables. The PTE were used as response variables while physical-chemical soil parameters used as explanatory variables. In the biplots both PTE and soil physical-chemical parameters are represented by arrows, indicating the direction of the maximum gradient in which the length of the arrow is proportional to the correlation of the characteristic with the axes and their importance in explaining the variance projected on each axis.

Values in the text indicate the mean \pm standard error of the mean.

\section{Results and discussion}

\subsection{Soil physical-chemical properties}

According to the huge pedovariability of selected representative soils (Supplementary file 1), a great variability was recorded in terms of physical-chemical and mineralogical properties (Table 1). The $\mathrm{pH}-\mathrm{H}_{2} \mathrm{O}$ ranged from 4.0 to 7.3 , with a mean of $5.2 \pm 0.1$, indicating the prevalence of acidic soils. The delta $\mathrm{pH}$ values $\left(\mathrm{pH}_{\mathrm{KCl}}-\mathrm{pH}_{\mathrm{H} 2 \mathrm{O}}\right)$ were negative for all the investigated pedotypes, showing that these soils were dominated by negative surface charges.

Data on particle size distribution (Table 1) shows a clay content ranging $40-716 \mathrm{~g} \mathrm{~kg}^{-1}$ (mean $305 \pm 35 \mathrm{~g} \mathrm{~kg}^{-1}$ ), a silt content ranging $20-448 \mathrm{~g} \mathrm{~kg}^{-1}\left(212 \pm 25 \mathrm{~g} \mathrm{~kg}^{-1}\right)$ and a sand content ranging
$75-880 \mathrm{~g} \mathrm{~kg}^{-1}\left(482 \pm 45 \mathrm{~g} \mathrm{~kg}^{-1}\right)$; consequently, soil texture varied considerably among the pedons with a mean prevalence of the loam one. Both $\mathrm{OC}$ and $\mathrm{P}$ contents were generally low, averaging $45.3 \pm 9.0 \mathrm{~g} \mathrm{~kg}^{-1}$ and $11.6 \pm 3.0 \mathrm{mg} \mathrm{kg}^{-1}$, respectively. Values for total CEC ranged from very low to very high with mean of $51.7 \pm 6.6$ $\mathrm{mmol}_{\mathrm{c}} \mathrm{kg}^{-1}$; however, the effective CEC, expressing the soil's expressing the soil's ability to retain cations when near the value of its natural $\mathrm{pH}$, was generally low (Table 1). In agreement with values observed for CEC and exchangeable cations, even base saturation (BS) greatly varied from very low (7\%) to high (95\%) values, averaging $49 \pm 5 \%$. According to mean values of the investigated oxides, they were representative of well developed and weathered soils of the tropical areas, as evidenced by their high wheatering indexes ( $\mathrm{Ki}$ and $\mathrm{Kr}$ of $2.2 \pm 0.2$ and $2.7 \pm 0.2$; respectively).

\subsection{Natural concentrations of PTE}

The mean natural background contents for selected PTE varied considerably among the investigated pedotypes (Figs. 2-3), with the following range of variation, in $\mathrm{mg} \mathrm{kg}^{-1}$ : As $=0.2-8.8$, $\mathrm{Ba}=2.9-548.3, \quad \mathrm{Cd}=0.01-0.48, \mathrm{Cr}=9.1-135.2, \quad \mathrm{Ni}=6.3-177.5$, $\mathrm{Pb}=2.0-50.6$, $\mathrm{Se}=0.01-0.70$, and $\mathrm{Zn}=4.0-68.5$.

The lowest PTE contents were observed in Oxisols and Entisols. They were in agreement with the main pedological and mineralogical properties since these soils are usually sandy. Soils developed on 

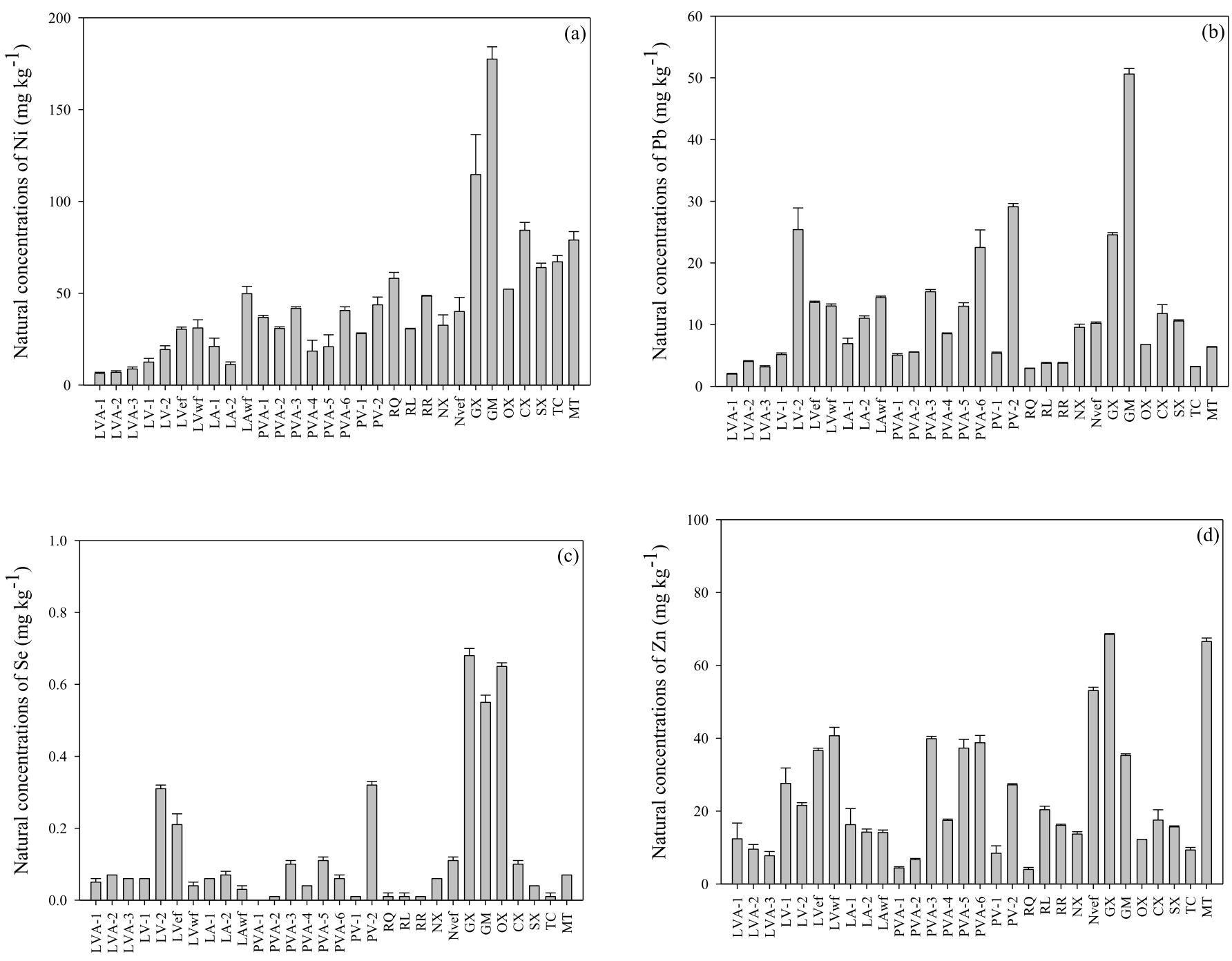

Fig. 3. Concentrations of $\mathrm{Ni} \mathrm{(a),} \mathrm{Pb}(\mathrm{b})$, Se (c) and $\mathrm{Zn}(\mathrm{d})$ in natural soils from São Paulo State, Brazil.

sedimentary and crystalline acid igneous rocks usually contain lower contents of PTE, as compared with those derived from basic rock, particularly those naturally enriched in metals (such as mafic rocks; Paye et al., 2010). The highest levels of PTE were generally observed in Mollisols, Histosols, Entisols, Inceptsols, Alfisols and Ultisols, all developed on basic igneous rocks such as basalt and diabase, richer in metals (Brazil Geological Service, 2004). These results are consistent with those obtained by Lopes (2009) and Biondi et al. (2011), showing that even under severe climatic conditions such as in the humid tropics, parent materials still play an important role in determining the content of most heavy metals in soils. On the other hand, the influence of pedogenesis cannot be negleted or underestimated, considering that the mean contents of PTE widely varied between samples of different Orders and within the same Order (Figs. 2-3). As a matter of fact, the increase in PTE concentration in the investigated soils is not only influenced by parent material, but also by the complexation of these metals with soil organic matter and adsorption onto silicate minerals/ oxides in oxidic soils (Kabata-Pendias and Mukherjee, 2007). In addition, the high contribution of soil texture to the natural metal content was evident (Supplementary file 1). As a matter of fact, soils of loamy (Oxisols) and sandy (Entisols) texture generally had the lowest PTEs concentration relative to clayey soils (Alfisols and Ultisols).

The mean natural background contents of PTE in the soils were in the following order, in $\mathrm{mg} \mathrm{kg}^{-1}: 54(\mathrm{Ba})>36(\mathrm{Cr})=36(\mathrm{Ni})>22$ $(\mathrm{Zn})>10(\mathrm{~Pb})>1.4(\mathrm{As}) \gg>0.1(\mathrm{Cd})=0.1(\mathrm{Se})$. These values are usually lower or close to those reported for soils of other countries and/ or other Brazilian states (Table 2). This demonstrates that the selected pedotypes belong to natural areas where the human impact was low and consequently, they can be considered as adequate benchmarks for PTE natural background values in the State of São Paulo. From a pedogeochemical point of view, these values reflect the low content of these metals in the parent materials of the State of São Paulo, mainly composed of metamorphic and sedimentary rocks (Oliveira et al., 2014).

\subsection{Soil quality reference values}

Since the natural background concentration of PTE had been quantified, the next step was to establish their normal distribution by using a box-plot analysis. This must be done (vide supra) in order to satisfy the following criteria ruled by Brazilian law: 1) removal of anomalous values, i.e., outliers, and 2) individuation of the 75th and the 90th percentile. The Brazilian legislation (CETESB, 2014) suggested that each state can select one of the two percentiles; however, the 75th is generally preferred by local governments and environmental agencies, because with the exclusion of $25 \%$ of the highest values it is considered more conservative and environmental-friendly; whereas, the 90th percentile is usually preferred by private companies and some scholars (Santos and Alleoni, 2013). Indeed, data used to obtain QRVs comes from soils that are broadly representative of a region; 
Table 2

Mean concentrations of PTE ( $\mathrm{mg} \mathrm{kg}^{-1}$ ) in natural soils from São Paulo State, as compared to the data compiled from the literature.

\begin{tabular}{|c|c|c|c|c|c|c|c|c|}
\hline Soils & As & $\mathrm{Ba}$ & $\mathrm{Cd}$ & $\mathrm{Cr}$ & $\mathrm{Ni}$ & $\mathrm{Pb}$ & $\mathrm{Se}$ & $\mathrm{Zn}$ \\
\hline \multicolumn{9}{|l|}{ International } \\
\hline Australia $^{\mathrm{a}}$ & NA & NA & 1.0 & 100.0 & 60.0 & 150.0 & NA & 1400.0 \\
\hline China $^{\mathrm{a}}$ & 9.2 & 450.0 & 0.07 & 53.9 & 23.4 & 23.6 & NA & 67.7 \\
\hline $\mathrm{USA}^{\mathrm{a}}$ & 5.2 & 440.0 & 1.6 & 37.0 & 12.4 & 16.0 & NA & 48.0 \\
\hline $\mathrm{Cuba}^{\mathrm{b}}$ & 10.8 & 128.7 & 1.2 & 463.2 & 294.2 & 34.6 & NA & 90.7 \\
\hline Spain $^{c}$ & 13.0 & 277.3 & NA & 38.1 & 36.2 & 46.9 & NA & 69.1 \\
\hline World soils ${ }^{\mathrm{d}}$ & $0.5-80.0$ & $84-960$ & $0.01-2.0$ & $5-1500$ & $2-750$ & $2-750$ & $0.05-0.50$ & $1-900$ \\
\hline \multicolumn{9}{|l|}{ Brazilian } \\
\hline Minas Gerais ${ }^{\mathrm{e}}$ & 17.8 & 190.9 & 0.5 & 100.1 & 30.1 & 3.9 & NA & 13.1 \\
\hline Paraná $^{f}$ & 7.2 & NA & 0.18 & 105.0 & 34.1 & 23.2 & NA & 75.2 \\
\hline Espírito Santo ${ }^{g}$ & 6.8 & NA & BDL & 41.1 & 6.6 & 8.8 & NA & 22.6 \\
\hline Mato Grosso e Rondônia ${ }^{\mathrm{h}}$ & NA & NA & BDL & 39.4 & 1.3 & 8.1 & NA & 6.8 \\
\hline Rio Grande do Norte ${ }^{\mathrm{i}}$ & NA & 43.9 & 0.07 & 23.0 & 14.0 & 10.9 & NA & 17.9 \\
\hline São Paulo ${ }^{j}$ & 1.34 & NA & $0.2-1.5$ & NA & NA & NA & 0.19 & NA \\
\hline \multicolumn{9}{|l|}{ This study } \\
\hline São Paulo & 1.38 & 54.1 & 0.1 & 36.6 & 36.0 & 10.1 & 0.12 & 21.8 \\
\hline
\end{tabular}

$\mathrm{NA}=$ not available; BDL $=$ below the detection limit.

a Chen et al. (1991).

b Alfaro et al. (2015).

c Tume et al. (2006) and Díez et al. (2009).

d Alloway (1995) and Kabata-Pendias and Mukherjee (2007).

e Caires (2009).

f MINEROPAR (2005).

$g$ Paye et al. (2010).

h Santos and Alleoni (2012).

i Preston et al. (2014).

j Gabos et al. (2014) and Oliveira et al. (2014).

Table 3

Soil quality reference values (QRVs) for some PTE in São Paulo State, Brazil $(n=30)$.

\begin{tabular}{lllllllll}
\hline Variable & As & \multicolumn{1}{c}{$\mathrm{Ba}$} & $\mathrm{Cd}$ & $\mathrm{Cr}$ & $\mathrm{Ni}$ & $\mathrm{Pb}$ & $\mathrm{Se}$ & $\mathrm{Zn}$ \\
\cline { 2 - 8 } & $\mathrm{mg} \mathrm{kg}$ & & & & & & & \\
\hline Mean & 1.38 & 54.15 & 0.10 & 36.66 & 36.05 & 10.11 & 0.12 & 21.84 \\
Maximum & 8.75 & 131.23 & 0.22 & 90.16 & 67.11 & 22.51 & 0.70 & 40.68 \\
Minimum & 0.18 & 15.72 & 0.04 & 15.02 & 11.16 & 4.04 & 0.01 & 8.43 \\
QRV/P 75 & 1.4 & 72 & 0.1 & 38 & 46 & 13 & 0.11 & 31 \\
QRV/P 90 & 2.0 & 103 & 0.2 & 63 & 57 & 15 & 0.32 & 38 \\
$\begin{array}{c}\text { State of São Paulo, } \\
\quad \text { Brazil }\end{array}$ & 3.5 & 75 & $<0.5$ & 40 & 13 & 17 & 0.25 & 60 \\
& & & & & & & & \\
\hline
\end{tabular}

$n=$ number of analyzed samples.

a QRVs proposed in this research obtained by the USEPA 3051A method, which is the official method for determining QRVs for Brazilian soils.

b QRVs established by CETESB (2014) for managing contaminated areas.

consequently, "anomalous" values could simply represent the natural pedovariability.

Considering both quartiles (Table 3), the QRVs for As $\left(75\right.$ th $=1.4 \mathrm{mg} \mathrm{kg}^{-1} ; \quad 90$ th $\left.=2.0 \mathrm{mg} \mathrm{kg}^{-1}\right), \quad$ Cd $\quad\left(0.1 \mathrm{mg} \mathrm{kg}^{-1}\right.$; $\left.0.2 \mathrm{mg} \mathrm{kg}^{-1}\right), \mathrm{Pb}\left(13 \mathrm{mg} \mathrm{kg}^{-1} ; 15 \mathrm{mg} \mathrm{kg}^{-1}\right)$, and $\mathrm{Zn}\left(31 \mathrm{mg} \mathrm{kg}^{-1}\right.$; $38 \mathrm{mg} \mathrm{kg}^{-1}$ ) are lower than that adopted by CETESB (2014). Values reported in this study come from really representative pedotypes under natural conditions. So, the current limits established by CETESB (2014) for these elements are extremely consistent. A different situation can be observed for $\mathrm{Ba} \quad\left(72 \mathrm{mg} \mathrm{kg}^{-1} ; 103 \mathrm{mg} \mathrm{kg}^{-1}\right), \quad \mathrm{Cr} \quad\left(38 \mathrm{mg} \mathrm{kg}^{-1}\right.$; $\left.63 \mathrm{mg} \mathrm{kg}^{-1}\right)$, and Se $\left(0.11 \mathrm{mg} \mathrm{kg}^{-1} ; 0.32 \mathrm{mg} \mathrm{kg}^{-1}\right)$. The 75 th percentile was similar to QRV proposed by CETESB (São Paulo State; CETESB, 2014), but higher if the QRV is ruled in agreements with the 90th percentile. The situation for Ni is even more different, since both percentiles (46 $\mathrm{mg} \mathrm{kg}^{-1} ; 57 \mathrm{mg} \mathrm{kg}^{-1}$ ) were higher than QRVs adopted by CETESB (2014). For all these elements, but with particular reference for $\mathrm{Ni}$, the QRV established by CETESB seems too restrictive and a little bit far from the real pedogeochemical conditions of the natural pedotypes characterizing the area. As a matter of fact, in most of the investigated pedons (Fig. 3a) the Ni concentration show a natural tendency towards high values, with the highest reached in clayey (such as Alfisols) and organic enriched (such as Mollisols and Alfisols) soils. Just in very few cases (Fig. 3a) Ni natural concentration was lower than $30 \mathrm{mg} \mathrm{kg}^{-1}$, and all these pedons were highly alternated, poor in organic matter content, and sandy-loam in texture (Oxisols). Previous studies have observed a close natural relationship between increments of $\mathrm{Ni}$ in soils according to clay, organic matter and, consequently, CEC content (Kabata-Pendias and Mukherjee, 2007). Such high values were mainly attributed to natural origins, as demonstrated by the correlation matrix (Table 4) where a significant relationship $(p<0.01)$ was observed between Ni vs. total CEC $(r=0.52)$ and OC $(r=0.60)$.

The QRVs determined in this study can be different from those of other states with different pedogeochemical, climatic, and land use conditions that affect natural background PTE concentration in soil. For instance, the QRV established by the State of Paraná (southern Brazil) is similar to that of this study for As (1.4 $\mathrm{mg} \mathrm{kg}^{-1}$ ) (Alleoni et al., 2013); however, the corresponding QRV in the State of Minas Gerais (centraleastern Brazil; $8.0 \mathrm{mg} \mathrm{kg}^{-1}$ ) is $471 \%$ higher and Pernambuco (northeastern Brazil; $0.6 \mathrm{mg} \mathrm{kg}^{-1}$ ) $57 \%$ lower (CPRH, 2014), as compared to this study (considering the 75th percentile). For soils of the State of Espírito Santo (south-eastern Brazil), Paye et al. (2010) suggested QRV for $\mathrm{Cd}\left(<0.13 \mathrm{mg} \mathrm{kg}^{-1}\right)$ and $\mathrm{Zn}\left(30 \mathrm{mg} \mathrm{kg}^{-1}\right)$, which are close to those observed in the present study; on the other hand, the QRVs for $\mathrm{Ni}$ $\left(9.17 \mathrm{mg} \mathrm{kg}^{-1}\right)$ and $\mathrm{Pb}\left(<4.54 \mathrm{mg} \mathrm{kg}^{-1}\right)$ were respectively $402 \%$ and $186 \%$ lower. In soils of Mato Grosso and Rondônia (southwestern Amazonian Brazil), Santos and Alleoni (2012) established QRVs for Ni (2.1 $\left.\mathrm{mg} \mathrm{kg}^{-1}\right), \mathrm{Pb}\left(9.0 \mathrm{mg} \mathrm{kg}^{-1}\right)$, and $\mathrm{Zn}\left(3.0 \mathrm{mg} \mathrm{kg}^{-1}\right)$, which are below those obtained in this study. In soils of Rio Grande do Norte (north-eastern Brazil; Preston et al., 2014), the QRVs are lower for Ba (59 $\left.\mathrm{mg} \mathrm{kg}^{-1}\right), \mathrm{Cr}\left(31 \mathrm{mg} \mathrm{kg}^{-1}\right)$, Ni $\left(20 \mathrm{mg} \mathrm{kg}^{-1}\right)$, and $\mathrm{Zn}\left(24 \mathrm{mg} \mathrm{kg}^{-1}\right)$, but similar for Cd $\left(0.1 \mathrm{mg} \mathrm{kg}^{-1}\right)$, as compared to this study. In Pernambuco, the QRVs established for $\mathrm{Cr}\left(35 \mathrm{mg} \mathrm{kg}^{-1}\right), \mathrm{Pb}\left(13 \mathrm{mg} \mathrm{kg}^{-1}\right)$, and $\mathrm{Zn}\left(35 \mathrm{mg} \mathrm{kg}^{-1}\right)$ are similar or close to those reported in the present study (CPRH, 2014). 
Table 4

Pearson correlation matrix between soil attributes and concentrations of PTE in the natural soils of São Paulo State, Brazil ( $n=30)$.

\begin{tabular}{|c|c|c|c|c|c|c|c|c|}
\hline Variable & As & $\mathrm{Ba}$ & $\mathrm{Cd}$ & $\mathrm{Cr}$ & $\mathrm{Ni}$ & $\mathrm{Pb}$ & $\mathrm{Se}$ & $\mathrm{Zn}$ \\
\hline As & 1.00 & & & & & & & \\
\hline $\mathrm{Ba}$ & ns & 1.00 & & & & & & \\
\hline $\mathrm{Cd}$ & $\mathrm{ns}$ & $0.87^{* *}$ & 1.00 & & & & & \\
\hline $\mathrm{Cr}$ & $\mathrm{ns}$ & ns & $\mathrm{ns}$ & 1.00 & & & & \\
\hline $\mathrm{Ni}$ & $\mathrm{ns}$ & ns & ns & $0.78^{* *}$ & 1.00 & & & \\
\hline $\mathrm{Pb}$ & $0.42 *$ & ns & ns & $0.55^{* *}$ & $0.64^{* *}$ & 1.00 & & \\
\hline Se & $\mathrm{ns}$ & ns & $\mathrm{ns}$ & $0.77^{* *}$ & $0.56^{* *}$ & $0.63^{* *}$ & 1.00 & \\
\hline $\mathrm{Zn}$ & ns & $0.79 * *$ & $0.77^{* *}$ & ns & $0.39^{*}$ & $0.43^{*}$ & $0.39 *$ & 1.00 \\
\hline OC & $\mathrm{ns}$ & ns & $\mathrm{ns}$ & $0.75^{* *}$ & $0.60 * *$ & $0.59 * *$ & $0.80 * *$ & ns \\
\hline $\mathrm{pH}_{(\mathrm{H} 2 \mathrm{O})}$ & $\mathrm{ns}$ & ns & ns & ns & $\mathrm{ns}$ & Ns & $\mathrm{ns}$ & ns \\
\hline $\mathrm{P}$ & $\mathrm{ns}$ & ns & $\mathrm{ns}$ & $0.51^{* *}$ & ns & Ns & $0.69^{* *}$ & $0.36^{*}$ \\
\hline K & ns & $0.45^{*}$ & $0.66^{* *}$ & ns & ns & Ns & ns & $0.70^{* *}$ \\
\hline $\mathrm{Ca}$ & ns & $0.83^{* *}$ & $0.86^{* *}$ & ns & ns & Ns & $\mathrm{ns}$ & $0.72^{* *}$ \\
\hline $\mathrm{Mg}$ & $\mathrm{ns}$ & $0.62^{*}$ & $0.70^{* *}$ & $\mathrm{~ns}$ & ns & Ns & $\mathrm{ns}$ & $0.67^{* *}$ \\
\hline $\mathrm{Al}$ & $\mathrm{ns}$ & $\mathrm{ns}$ & $\mathrm{ns}$ & $0.70 * *$ & $0.51 *$ & $0.46^{*}$ & $0.72^{* *}$ & $\mathrm{~ns}$ \\
\hline $\mathrm{H}+\mathrm{Al}$ & $\mathrm{ns}$ & ns & ns & $0.81^{* *}$ & $0.62^{* *}$ & $0.61 * *$ & $0.75^{* *}$ & ns \\
\hline SB & $\mathrm{ns}$ & $0.79 * *$ & $0.85^{* *}$ & ns & $\mathrm{ns}$ & Ns & ns & $0.74 * *$ \\
\hline $\mathrm{CEC}_{\mathrm{t}}$ & $\mathrm{ns}$ & $0.63^{* *}$ & $0.60 * *$ & $0.66^{* *}$ & $0.52^{* *}$ & $0.55^{* *}$ & $0.63^{*}$ & $0.69^{* *}$ \\
\hline $\mathrm{CEC}_{\mathrm{e}}$ & $\mathrm{ns}$ & $0.68^{* *}$ & $0.65^{* *}$ & ns & ns & $0.49 * *$ & $0.55^{*}$ & $0.67^{* *}$ \\
\hline BS & $\mathrm{ns}$ & $0.37^{*}$ & $0.47^{* *}$ & ns & ns & Ns & ns & $0.36^{*}$ \\
\hline$m$ & $\mathrm{~ns}$ & ns & $-0.46^{* *}$ & ns & $\mathrm{ns}$ & Ns & $\mathrm{ns}$ & $-0.39^{*}$ \\
\hline Variable & As & $\mathrm{Ba}$ & $\mathrm{Cd}$ & $\mathrm{Cr}$ & $\mathrm{Ni}$ & $\mathrm{Pb}$ & $\mathrm{Se}$ & $\mathrm{Zn}$ \\
\hline $\mathrm{SiO}_{2(\mathrm{AE})}$ & $\mathrm{ns}$ & $0.62^{* *}$ & $0.55^{* *}$ & $0.71^{* *}$ & $0.55^{* *}$ & $0.58^{* *}$ & $0.70 * *$ & $0.77^{* *}$ \\
\hline $\mathrm{Al}_{2} \mathrm{O}_{3(\mathrm{SA})}$ & $\mathrm{ns}$ & ns & $0.41 *$ & $0.47^{* *}$ & $\mathrm{~ns}$ & $0.52^{* *}$ & $0.47^{*}$ & $0.55^{* *}$ \\
\hline $\mathrm{Fe}_{2} \mathrm{O}_{3(\mathrm{SA})}$ & $\mathrm{ns}$ & $0.43^{*}$ & $0.63^{* *}$ & ns & ns & Ns & ns & $0.58^{* *}$ \\
\hline $\mathrm{Mn}_{2} \mathrm{O}_{3(\mathrm{SA})}$ & $\mathrm{ns}$ & $0.79 * *$ & $0.92^{* *}$ & $\mathrm{~ns}$ & ns & Ns & $\mathrm{ns}$ & $0.77^{* *}$ \\
\hline $\mathrm{TiO}_{2(\mathrm{SA})}$ & ns & $0.50 * *$ & $0.69 * *$ & $\mathrm{~ns}$ & ns & Ns & $\mathrm{ns}$ & $0.62 * *$ \\
\hline $\mathrm{Ki}$ & $\mathrm{ns}$ & ns & ns & ns & ns & Ns & $\mathrm{ns}$ & ns \\
\hline $\mathrm{Kr}$ & $\mathrm{ns}$ & $0.46^{*}$ & $0.42 *$ & ns & ns & Ns & ns & ns \\
\hline $\mathrm{Fe}_{2} \mathrm{O}_{3}$ (CBD) & $\mathrm{ns}$ & ns & $0.59^{* *}$ & ns & ns & Ns & $\mathrm{ns}$ & $0.51^{* *}$ \\
\hline $\mathrm{Fe}_{2} \mathrm{O}_{3}$ (OXA) & $\mathrm{ns}$ & $\mathrm{ns}$ & $0.53^{* *}$ & $\mathrm{~ns}$ & ns & Ns & $\mathrm{ns}$ & $0.47^{* *}$ \\
\hline $\mathrm{Al}_{2} \mathrm{O}_{3}$ (OXA) & $\mathrm{ns}$ & ns & $0.55^{* *}$ & ns & ns & Ns & $\mathrm{ns}$ & $0.47^{* *}$ \\
\hline $\mathrm{Mn}_{2} \mathrm{O}_{3}$ (OXA) & $\mathrm{ns}$ & $\mathrm{ns}$ & $0.63^{* *}$ & $\mathrm{~ns}$ & ns & Ns & $\mathrm{ns}$ & $0.46^{* *}$ \\
\hline Clay & ns & $0.49^{* *}$ & 0.61 ** & $\mathrm{ns}$ & ns & $0.51^{* *}$ & $0.41 *$ & $0.71^{* *}$ \\
\hline Silt & ns & ns & ns & $0.39 *$ & ns & Ns & ns & ns \\
\hline Sand & $\mathrm{ns}$ & $-0.54^{* *}$ & $-0.62^{* *}$ & $-0.46^{* *}$ & ns & $-0.56^{* *}$ & $-0.53^{* *}$ & $-0.70^{* *}$ \\
\hline
\end{tabular}

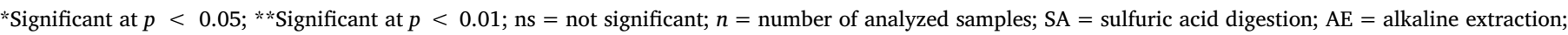
$\mathrm{OXA}=$ ammonium oxalate; $\mathrm{CBD}=$ sodium citrate-bicarbonate-dithionite.

The differences in the QRVs proposed for the soils between the State of São Paulo and other Brazilian states can be attributed to the huge diversity of physical-chemical and mineralogical composition of the soils, parent materials, climatic conditions and pedogenetic processes (Preston et al., 2014).

The adoption of QRVs for PTE in soils is a first step in environmental quality monitoring actions (Paye et al., 2010). These values should be applied in areas with similar pedogeochemical conditions. It is essential to obtain QRVs for each region of the country, especially with huge geological, geomorphological, climatic, and pedological differences, like Brazil (Santos and Alleoni, 2012).

\subsection{Multivariate statistic}

Some differences were observed in PTEs baseline values, and relative QRVs, in this study and those reported by CETESB (2014) for the State of São Paulo or even with those established by other studies for different States. It is important to understand if such differences may well be the product of naturally enhanced concentrations and/or anthropogenic contamination. Additionally, it is also necessary to investigate which were the main variables (or group of) responsible for the observed variability inside the investigated pedosystem. From this point of view, comparing distributions of elements with pedological information can be a great help in identifying and distinguishing sources of PTE in soil. Indeed, correlation matrix (CM) and multivariate analysis, through principal component analysis (PCA), can help distinguish between natural geogenic, pedogenic, and, or anthropogenic sources (Capra et al., 2014).

\subsubsection{Correlation matrix}

Correlation matrix (CM) on Box-Cox transformed data was used to identify the relationship between PTE content and soil properties in the investigated soils (Table 4).

Correlations exist among all the PTEs couples, according to their pedogeochemical affinity (such as Ba-Cd, Ba-Zn, Cd-Zn, Cr-Ni, Cr-Pb, $\mathrm{Cr}$-Se). Primary factors such as geogenic and pedogenic nature influence the concentration and distribution of elements in the investigated soils. The "geogenic" factor includes a part of "pedogenic" processes. The geogenic influence can be explained by the similarity of the investigated PTE in terms of their physical-chemical properties (atomic mass, ionic radius, and oxidation state) and the coexistence during the formation of the minerals (Kabata-Pendias and Mukherjee, 2007). The "pedogenic" component, is clearly related to several soil physical-chemical properties. For instance, organic carbon (OC) had a positive linear relationship with $\mathrm{Cr}(r=0.75, p<0.01)$, Ni $(r=0.60$, $p<0.01), \mathrm{Pb}(r=0.59, p<0.01)$, and Se $(r=0.80, P<0.01)$ (Table 4); a correlation that was also reported by other authors and explained in terms of binding power of soil organic matter (KabataPendias and Mukherjee, 2007; Coppola et al., 2010; Capra et al., 2014).

Cadmium, Zn, or Ba was positively correlated with $\mathrm{Ca}, \mathrm{Mg}, \mathrm{SB}, \mathrm{CEC}$, $\mathrm{BS}$, oxides of $\mathrm{Si}, \mathrm{Fe}, \mathrm{Mn}$ and $\mathrm{Ti}, \mathrm{Kr}$ and clay, whereas there was a negative correlation between each of these elements and sand contents (Table 4). The silicate minerals of clay fraction and oxides have been reported as the main attributes that correlated with the natural contents of Cd and other metals in soil (Alleoni et al., 2005). Biondi et al. (2011) also reported that clay content was best correlated with these metals. Positive correlations between clay vs. oxides and heavy metal content 


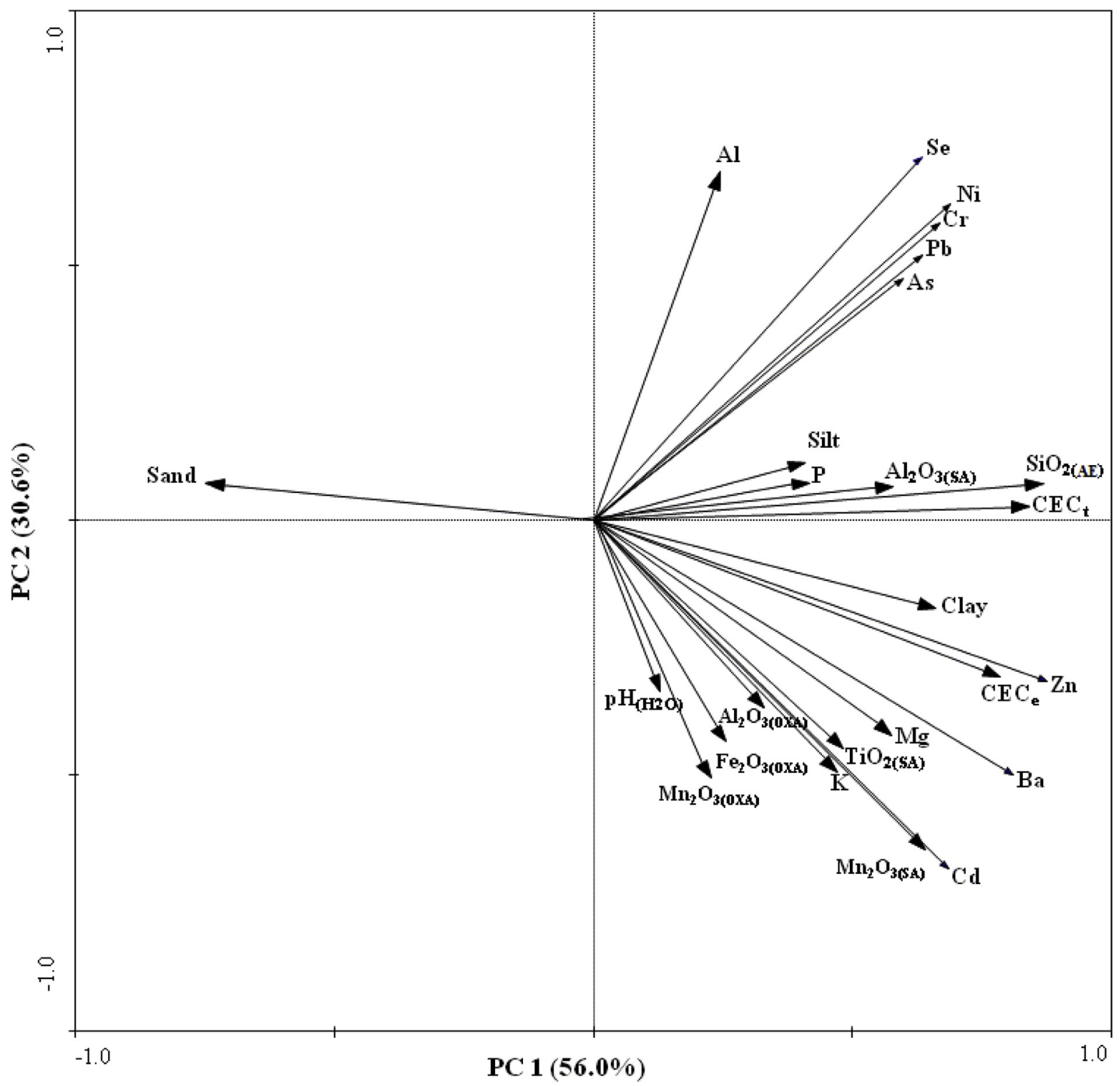

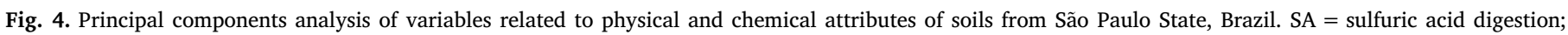
$\mathrm{AE}=$ alkaline extraction; $\mathrm{OXA}=$ ammonium oxalate.

were reported by other studies (Oliveira et al., 2014; Gabos et al., 2014) in natural soils. The natural concentration of $\mathrm{Cr}$ in the investigated soils was positively correlated with $\mathrm{P}, \mathrm{Al}, \mathrm{H}+\mathrm{Al}, \mathrm{CEC}_{\mathrm{t}}$, $\mathrm{Si}$ and $\mathrm{Al}$ oxides, and silt contents. Negative correlation was noted between $\mathrm{Cr}$ content and sand content. As with $\mathrm{Cr}$, Ni content showed a positive relation with $\mathrm{OC}, \mathrm{Al}, \mathrm{H}+\mathrm{Al}, \mathrm{CECt}$ and $\mathrm{Si}$ oxide. The natural concentration of $\mathrm{Pb}$ was positively correlated with $\mathrm{Al}, \mathrm{H}+\mathrm{Al}, \mathrm{CEC}_{\mathrm{t}}, \mathrm{CEC}_{\mathrm{e}}$, and $\mathrm{Si}$ and $\mathrm{Al}$ oxides; had a positive correlation with clay content but a negative relation with sand. These results corroborate those reported by Santos and Alleoni (2013), especially regarding the influence of soil texture. It is well known that clay fraction has higher affinity for heavy metals, such as $\mathrm{Pb}$, and thus limits their mobility through adsorption processes (Biondi et al., 2011). The natural concentration of Se showed an high positive correlation with $\mathrm{OC}, \mathrm{SiO}_{2}, \mathrm{Al}_{2} \mathrm{O}_{3}, \mathrm{P}, \mathrm{CEC}, \mathrm{Al}, \mathrm{H}+\mathrm{Al}$, or clay (Table 4). These correlations explained the lower Se concentration in the soils with lower CEC, OC, and clay contents. SOM and $\mathrm{Fe}$ and $\mathrm{Al}$ oxides were attributes strongly related to the natural levels of Se in Brazilian soils (Gabos et al., 2014). The significant correlations of $\mathrm{Se}_{-} \mathrm{Al}_{2} \mathrm{O}_{3}$, Se-clay and Se-P confirm the claims of Alleoni et al. (2009) that higher concentrations of Se, and other PTE in Oxisols and Ultisols (Fig. 3c) were usually associated with the richness of parent materials and adsorption reactions. It is interesting to note the positive relationship of Se concentration with $\mathrm{Si}, \mathrm{Fe}, \mathrm{Al}, \mathrm{Mn}$ and $\mathrm{Ti}$ oxides, and a negative correlation between clay and sand fraction (Table 4). pH, CEC, OC, clay content and type (silica clays and oxides) and ionic competition seem to have most influence on the retention and mobility of $\mathrm{Zn}$ and other heavy metals in the investigated soil, as reported in previous reports (Qian et al., 1996; Fontes et al., 2000). Fe, Al, Si, Mn and Ti were the attributes that were most correlated with $\mathrm{Ba}, \mathrm{Cd}$, and $\mathrm{Zn}$ concentrations in soils under a humid tropical climate; in such conditions soils are characterized by a high degree of weathering with $\mathrm{Fe}$ and $\mathrm{Al}$ oxides playing an important role in the behavior of heavy metals (Alleoni et al., 2005).

\subsubsection{Principal components analysis}

As a final step, the PCA has been elaborated in order to understand most important variables for the variability in the investigated soils. PC1 and PC2 explained $56.0 \%$ and $30.6 \%$ of the total variability, 
respectively (Fig. 4). Together they accounted for $87 \%$ of the total variability. The PCA results strongly support previous observations reported through the analysis of matrix correlation. The PCA reveled two main distinct clusters of statistical significance (Fig. 4); the first is of mainly geogenic origin, and the second more related to enanched pedogenic influence. In the first (geogenic) cluster, major relationships were noted between $\mathrm{As}, \mathrm{Pb}, \mathrm{Cr}, \mathrm{Ni}$, and Se, evidencing a strong geochemical affinity among these metals. Previous studies already reported a close relationship between As and $\mathrm{Pb}$ (Zhang et al., 2002), $\mathrm{Cr}$ and $\mathrm{Ni}$ (Zhang et al., 2002; Tume et al., 2006; Santos and Alleoni, 2013), Ba and Zn (Tume et al., 2006), Cd and Pb (Anju and Banerjee, 2011), and $\mathrm{Cd}$ and $\mathrm{Zn}$ (Aravind and Prasad, 2005) in natural soils. The second cluster showed that several soil physical-chemical parameters (such as $\mathrm{CEC}$, clay, and $\mathrm{pH}$ ) had a great influence on the variation of the components that are associated with metals such as $\mathrm{Zn}, \mathrm{Ba}, \mathrm{Cd}$. Oxides of $\mathrm{Al}$, $\mathrm{Fe}, \mathrm{Mn}, \mathrm{Si}$, clay and CEC were already proved to be the attributes that have a close association with content of Cd and other PTE in natural soils of the State of São Paulo (Oliveira et al., 2014).

On the whole, the PCA corroborates the hyphotesis about the (co) existence of two main groups of primary factors responsible for PTE source: geogenic origin being a prevalent one, and pedogenic processes as secondary, in terms of their influence in the PTE source and variability.

\section{Conclusions}

The mean values of natural PTE background content in the soils of the State of São Paulo are generally lower than those reported in other countries and/or other Brazilian states. The less restrictive 90th percentile, as upper limit for QRV, appears to be adequate.

Multivariate statistical analysis showed that the investigated PTE in the soils were mainly originated from the two natural sources: 1) geogenic, that is prevalent in terms of underlying processes and variability; and 2) pedogenic, that is fundamental in several observed processes, with anthropogenic influence being marginal.

Studies at regional scale are necessary to determine the natural background levels of PTEs into the soils, and this is important to avoid the use of data based on regions with different pedogeochemical conditions, that could brings to either over or under estimates in soil contamination.

\section{Acknowledgments}

This study was supported by a Ph.D graduate scholarship awarded to the first author (grant \# 07/59402-0) from The State of São Paulo Research Foundation (FAPESP), the Center for Nuclear Energy in Agriculture/University of São Paulo (CENA/USP), and the University of Florida. To Brazilian Council for Scientific and Technological Development (CNPq), for the Research Grant to the 3rd author. The first author is also grateful to Professor Eurípedes Malvolta (in memoriam) for encouragement and motivation during his Ph.D at CENA/USP.

\section{Appendix A. Supplementary data}

Supplementary data related to this article can be found at http://dx. doi.org/10.1016/j.jenvman.2018.05.048.

\section{References}

Alfaro, M.R., Montero, A., Ugarte, O.M., Nascimento, C.W., Aguiar Accioly, A.M., Biondi, C.M., Silva, Y.J., 2015. Background concentrations and reference values for heavy metals in soils of Cuba. Environ. Monit. Assess. 187, 4198-4208.

Alleoni, L.R.F., Iglesias, M.S.C., Mello, S.C., Camargo, O.A., Casagrande, J.C., Lavorenti, N.A., 2005. Soil attributes related to cadmium and copper adsorption in tropical soils. Acta Sci. Agron. 27, 729-737.

Alleoni, L.R.F., Camargo, O.A., Casagrande, J.C., Soares, M.R., 2009. Química dos solos altamente intemperizados. In: Mello, V.F., Alleoni, L.R.F. (Eds.), Química e
Mineralogia do Solo. Sociedade Brasileira do Solo, Viçosa, pp. 381-447.

Alleoni, L.R.F., Fernandes, A.R., Santos, S.N., 2013. Valores referência de elementos potencialmente tóxicos nos estados do Pará, Rondônia e Mato Grosso. Boletim Informativo SBCS 38, 18-21.

Alloway, B.J., 1995. Heavy Metals in Soils. Blackie Academic and Professional, Glasgow. Almeida Júnior, A.B., Nascimento, C.W.A., Biondi, C.M., Souza, A.P., Barros, F.M.R., 2016. Background and reference values of metals in soils from Paraíba state, Brazil. Rev. Bras. Cienc. Solo 40 e0150122.

Anju, M., Banerjee, D.K., 2011. Associations of cadmium, zinc and lead in soils from a lead and zinc mining area as studied by single and sequential extractions. Environ. Monit. Assess. 176, 67-85.

Aravind, P., Prasad, M.N.V., 2005. Cadmium-zinc interactions in a hydroponic system using Ceratophyllum demersum L.: adaptative ecophysiology, biochemistry and molecular toxicology. Braz. J. Plant Physiol. 17, 3-20.

Biondi, C.M., Nascimento, C.W.A., Neta, A.B.F., Ribeiro, M.R., 2011. Concentrations of $\mathrm{Fe}, \mathrm{Mn}, \mathrm{Zn}, \mathrm{Cu}, \mathrm{Ni}$ and $\mathrm{Co}$ in benchmark soils of Pernambuco. Rev. Bras. Cienc. Solo 35, 1057-1066.

Brazil Geological Service, 2004. Carta Geológica do Brasil ao Milionésimo: sistema de informações geográficas-SIG [Geological Map of Brazil 1:1.000.000 scale: geographic information system-GIS]. CPRM, Brasília.

Caires, S.M., 2009. Determination of Natural Heavy Metals Levels in Soils of Minas Gerais State to Help Definition of Background Levels. PhD Thesis. Federal University of Viçosa, Viçosa.

Capra, G.F., Coppola, E., Odierna, P., Grilli, E., Vacca, S., Buondonno, A., 2014. Occurrence and distribution of key potentially toxic elements (PTEs) in agricultural soils: a paradigmatic case study in an area affected by illegal landfills. J. Geochem. Explor. 145, 169-180.

CETESB-Environmental Agency of the State of São Paulo, 2014. Report Establishment of Guiding Values for Soil and Groundwater in the State of São Paulo. CETESB, São Paulo Available at. http://www.CETESB.sp.gov.br/userfiles/file/solo/valoresorientadores-2014.pdf, Accessed date: 6 October 2017.

CETESB-Environmental Agency of the State of São Paulo, 2016. Decisão de Diretoria № 256/2016/E, de 22 de Novembro de 2016. CETESB, São Paulo Available at. http:// www.cetesb.sp.gov.br/wp-content/uploads/sites/11/2014/12/DD-256-2016-EValores-Orientadores-Dioxinas-e-Furanos-2016-Intranet.pdf, Accessed date: 6 October 2017.

Chen, J., Wei, F., Zheng, C., Wu, Y., Adrian, D.C., 1991. Background concentrations of elements in soils of China. Water Air Soil Pollut. 57-58, 699-712.

Chrzan, A., 2016. Monitoring bioconcentration of potentially toxic trace elements in soils trophic chains. Environ. Earth Sci. 75, 786.

CONAMA-Conselho Nacional Do Meio Ambiente, 2009. Brazilian National Environment Council, Resolution \# 420. CONAMA, Brasilia Available at. http://www.mma.gov. br/port/conama/legiabre.cfm?codlegi0620, Accessed date: 6 October 2017.

Coppola, E., Capra, G.F., Odierna, P., Vacca, S., Buondonno, A., 2010. Lead distribution as related to pedological features of soils in the Volturno River low Basin (Campania, Italy). Geoderma 159, 342-349.

CPRH-Pernambuco Environmental Protection Agency, 2014. Instrução Normativa CPRH \# 007/2014. CPRH, Brasilia Available at. http://www.jusbrasil.com.br/diarios/ 82838343/doepe-31-12-2014-pg-13/pdfView, Accessed date: 4 October 2017.

Díez, M., Simón, M., Martín, F., Dorronsoro, C., García, I., Van Gestel, C.A.M., 2009. Ambient trace element background concentrations in soils and their use in risk assessment. Sci. Total Environ. 407, 4622-4632.

Fontes, M.P.F., Matos, A.T., Neves, J.C.L., 2000. Competitive adsorption of Zn, Cd, Cu and $\mathrm{Pb}$ in three highly weathered Brazilian soil. Commun. Soil Sci. Plant Anal. 31, 2939-2958.

Gabos, M.B., Alleoni, L.R.F., Abreu, C.A., 2014. Background levels of selenium in some selected Brazilian tropical soils. J. Geochem. Explor. 145, 35-39.

IBGE-Brazilian Geography and Statistics Institute, 2014. Diretoria de Pesquisas, Coordenação de Trabalho e Rendimento, Pesquisa Nacional por Amostra de Domicílios Contínua 2014. IBGE, Rio de Janeiro Available in. http://www.ibge.gov. br/estadosat/perfil.php?sigla=s, Accessed date: 9 June 2015.

INMETRO-National Institute of Metrology, Quality and Technology, 2003. . DOQCGCRE-008. Orientações Sobre Validação de Métodos de Ensaios Químicos. INMETRO, Rio de Janeiro Available at. http://www.inmetro.gov.br/Sidoq/ Arquivos/CGCRE/DOQ/DOQ-CGCRE- 8 02.pdf, Accessed date: 6 June 2017.

Kabata-Pendias, A., Mukherjee, A.B., 2007. Trace Elements from Soil to Human. SpringerVerlag, Berlin.

Lopes, C.M., 2009. Individual and Competitive Adsorption of Cd, Cu, Ni and $\mathrm{Zn}$ in Soils as a Function of PH Variation. Master's Thesis. Luiz de Queiroz College of Agriculture, University of São Paulo, Piracicaba.

Malkoc, S., Yazici, B., 2017. Multivariate analyses of heavy metals in surface soil around an organized industrial area in Eskisehir, Turkey. Bull. Environ. Contam. Toxicol. 98 (2), 244-250.

MINEROPAR-Minerais do Paraná SA, 2005. Geoquímicha de Aolo. Mineropar, Curitiba.

Oliveira, V.H., Abreu, C.A., Coelho, R.M., Melo, L.C.A., 2014. Cadmium background concentrations to establish reference quality values for soils of São Paulo State. Brazil. Environ. Monit. Assess 186, 1399-1408.

Paye, H.S., Mello, J.W.V., Abrahão, W.A.P., Fernandes Filho, E.I., Dias, L.C.P., Castro, M.L.O., Melo, S.B., França, M.M., 2010. Reference quality values for heavy metals in soils from Espírito Santo State, Brazil. Rev. Bras. Cienc. Solo 34, 2041-2051.

Preston, W., Nascimento, C.W.A., Biondi, C.M., Souza Junior, V.S., Silva, W.R., Ferreira, H.A., 2014. Quality reference values for heavy metals in soils of Rio Grande do Norte, Brazil. Rev. Bras. Cienc. Solo 38, 1028-1037.

Qian, J., Shan, X., Wang, Z., Tu, Q., 1996. Distribution and plant availability of heavy metals in different particle-size fractions of soil. Sci. Total Environ. 186, 131-141.

Raij, B., Andrande, J.C., Cantarella, H., Quaggio, J.A. (Eds.), 2001. Análise Química Para 
Avaliação da Fertilidade de Solos Tropicais. Instituto Agronômico, Campinas.

Santos, S.N., Alleoni, L.R.F., 2012. Methods for extracting heavy metals in soils from the southwestern Amazon, Brazil. Water Air Soil Pollut. 224, 1430-1446.

Santos, S.N., Alleoni, L.R.F., 2013. Reference values for heavy metals in soils of the Brazilian agricultural frontier in Southwestern Amazônia. Environ. Monit. Assess. 185, 5737-5748.

SAS Institute, 2010. SAS Online DocVersion 9.2. SAS Institute Inc., Cary.

Schoeneberger, P.J., Wysocki, D.A., Benham, E.C., Staff, Soil Survey (Eds.), 2012. Field Book for Describing and Sampling Soils. Version 3.0, Natural Resources Conservation Service. National Soil Survey Center, Lincoln.

Seibel, F., 2007. O Novo Salto Do Agronegócio. Exame. pp. 14-21 special issue.

Silva, F.L., Pierangeli, M.A.P., Santos, F.A.S., Serafim, M.E., Souza, C.A., 2017. Natural backgrounds and reference values of trace-element in earth murundus fields on the Southern Amazon. Brazil. J. Agric. Sci. 12, 172-178.

Soil Survey Staff, 2014. Keys to Soil Taxonomy, twelfth ed. USDA-NRCS. US Gov. Print. Office, Washington, DC

Ter Braak, C.J.F., Smilauer, P., 1998. CANOCO: Reference Manual and User's Guide to Canoco for Windows: Software for Canonical Community Ordination (Version 4).
Microcomputer Power, Ithaca

Tume, P., Bech, J., Longan, L., Tume, L., Reverter, F., Sepulvedae, B., 2006. Trace elements in natural surface soils in Sant Climent (Catalonia, Spain). Ecol. Eng. 27, $145-152$.

USDA-United States Department of Agriculture, 2017. World Agricultural Production. Circular Series WAP 07-17. Foreign Agricultural Service, Washington, DC.

USEPA-United States Environmental Protection Agency, 1996. Soil Screening Guidance: Technical Background Document. EPA, Office of Solid Waste and Emergency Response, Washington, DC.

USEPA-United States Environmental Protection Agency, 2007. Method 3051A Microwave Assisted Acid Digestion of Sediments, Sludges, Soils, and Oils. USEPA USEPA, Washington, DC Available in. http://www.epa.gov/osw/hazard/ testmethods/sw846/pdfs/3051a.pdf, Accessed date: 7 June 2015.

Zhang, X.P., Deng, W., Yang, X.M., 2002. The background concentrations of 13 soil trace elements and their relationships to parent materials and vegetation in Xizang (Tibet), China. J. Asian Earth Sci. 21, 167-174.

Zhao, F.J., McGrath, S.P., Merrington, G., 2007. Estimates of ambient background concentrations of trace metals in soils for risk assessment. Environ. Pollut. 148, 221-229. 